УДК 622.278

\title{
ПЕРСПЕКТИВЫ ИСПОЛЬЗОВАНИЯ ТЕПЛОВОЙ ЭНЕРГИИ ВОДОНОСНЫХ ГОРИЗОНТОВ ПРИ ПОДЗЕМНОМ СЖИГАНИИ УГЛЯ
}

Садовенко И.А., докт. техн. наук, Инкин А.В., канд. техн. наук

Государственное высшее учебное заведение «Наџииональный горный университет» МОН Украины, пр. К. Маркса 19, Днепропетровск, 49600, Украина

За результатами моделювання фільтрації і теплоперенесення встановлена конвективна i кондуктивна складова теплового потоку, що проникає 3 підземного газогенератора у вищезалягаючий водоносний горизонт. Дані оцінки зміни величини потоку i температури підземних вод в залежності від потужності водотривкого шару.

Библ. 9, рис. 5.
По результатам моделирования фильтрации и теплопереноса установлена конвективная и кондуктивная составляющая теплового потока, проникающего из подземного газогенератора в вышезалегающий водоносный горизонт. Даны оценки изменения величины потока и температуры подземных вод в зависимости от мощности водоупорного слоя.
As a result of filtration and heat transfer modeling of convective and conductive installed component of the heat flux penetrating the underground gasifier in the upper aquifer. The estimates varying the flow and temperature of groundwater, depending on the capacity impermeable layer deterioration.

Ключевые слова: подземное сжигание угля, тепловая энергия, подземные воды.

$a-$ коэффициент температуропроводности;

$C$ - содержание;

$c$ - теплоемкость;

$D$ - расход дутья;

$F-$ площадь;

$H$ - глубина залегания газогенератора;

$l$ - длина;

$P$ - давление;

$Q$ - теплота сгорания;

$q$ - тепловой поток;

$S$ - площадь теплообмена;

$T$ - температура;

$t$ - время;

$V$ - количество;

$W$ - влажность;

$z$ - вертикальная координата;

$\alpha$ - опытный коэффициент;

$\kappa-$ проницаемость;

$\lambda$ - коэффициент теплопроводимости;

$\mu-$ вязкость;

\section{Введение}

По оценкам ведущих нефтегазовых компаний, начало XXI века ознаменовалось значительным увеличением доли угля в топливно-энер- $\rho-$ плотность;

$\vartheta$ - объемный поток;

$\mathrm{O}$ - дебит;

П - производительность подземного газогенератора; Э - эффективность канала газификации;

\section{Индексы нижние:}

$c d$ - кондуктивный;

$c v$ - конвективный;

$o$ - суммарный;

$s k$ - скважина;

атм - атмосферное;

в - воздух;

$\Gamma-$ газ;

П- пород;

пв - подземные воды;

у- уголь;

уг - углерод;

уг. комп. - углесодержащие компоненты;

уп - угольный пласт.

гетическом балансе Украины и ряда стран мира (рис. 1). Рост его потребления был вызван, с одной стороны, ограниченностью запасов нефти и природного газа, а также перемещением разрабаты- 
ваемых месторождений в труднодоступные районы, с другой стороны, проблемами безопасности атомных электростанций и высокими затратами на захоронение радиоактивных отходов [1]. Вместе с тем, увеличение добычи и переработки угля традиционными способами привело к превращению угледобывающих регионов в зоны экологического бедствия. Так, работа небольшой угольной электростанции мощностью 200 МВт сопровождается ежегодным выбросом в атмосферу 100 тыс. т твердых частиц, 15 тыс. т сернистых соединений и 2 тыс. т окислов азота.
Расширение сферы использования угольных ресурсов возможно путем их преобразования на месте залегания в экологически более чистый газообразный энергоноситель. Наиболее технически освоенным процессом такой переработки является подземное сжигание угля (ПСУ). Однако, несмотря на почти вековой научнопромышленный опыт развития, оно до сих пор не получило широкого распространения ввиду значительного рассеивания вырабатываемой тепловой энергии в породном массиве [2].

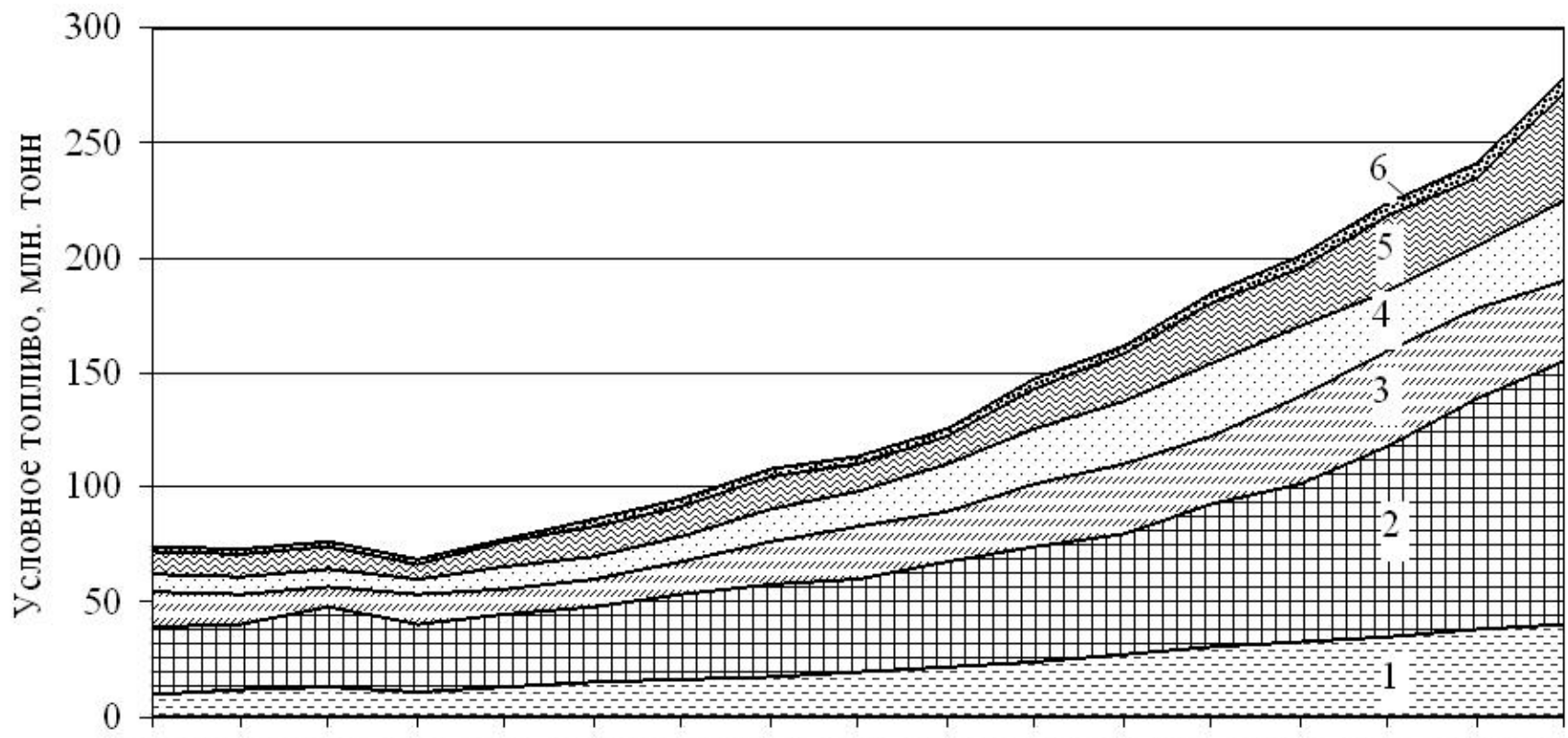

20002003200620092012201520182021202420272030203320362039204220452048

Годы

Рис. 1. Прогноз потребления энергии Украиной за счет:

1 - 6 топливных масел, природного газа, теплоносителей, электричества, уаля и биомассы соответственно.

\section{Постановка задачи}

Для повышения КПД данной геотехнологии (отношение используемого тепла к теплоте сгорания топлива) в работе [3] уже была установлена возможность отбора части тепловой энергии поступающей из реакционного канала в покрывающие его породы. Кроме того, об этом свидетельствуют результаты крупнейшего научно-промышленного эксперимента по ПСУ на участке Роки Маунтин в США [4]. Однако для практических расчетов количества и выбора рациональной схемы извлече- ния накапливаемой тепловой энергии необходима детальная характеристика возникающего теплового потока и оценка влияния на него горно-геологических условий разрабатываемого угольного участка. В связи с чем, целью данной работы является установление динамики формирования теплового поля вокруг подземного газогенератора и возможности отбора нагреваемых им подземных вод для теплоснабжения гражданских и промышленных объектов.

Подготовка угольного участка к подземному 
сжиганию начинается с бурения нагнетательной и газоотводящей скважины. Для взаимодействия угля с дутьем в пласте между скважинами создается реакционный канал, при образовании которого применяют фильтрационную, гидроразрывную, электрическую и буровую сбойки. После сбойки скважин происходит поджиг угля и подача химических реагентов (воздуха, кислорода или водяного пара) в виде дутья через нагнетательную скважину. Участок угольного пласта, где ведется сжигание (подземный газогенератор), условно можно разделить на четыре зоны, которым соответствуют различные реакции горения, и на каких основан процесс ПСУ (рис. 2). Образованный в результате горения газ по продуктивной скважине выводится на поверхность и через трубопровод попадает в установки для охлаждения и очистки. Утилизация его физического тепла производится в теплообменниках, работающих в широких диапазонах: высоко (800...600 $\left.{ }^{\circ} \mathrm{C}\right)$, средне $\left(600 \ldots 400{ }^{\circ} \mathrm{C}\right)$ и низкотемпературном $\left(400 \ldots 150{ }^{\circ} \mathrm{C}\right)$.

Согласно приведенной технологической схеме разработки и геологического строения угольных месторождений теплообменная система подземного газогенератора состоит из трёх пластов, имеющих непосредственный контакт друг с другом. В процессе сжигания нижнего угольного пласта часть тепла расходуется для перехода в горючие компоненты, другая часть поступает во вмещающие породы. Так как нагретые продукты горения значительно легче дутьевых компонентов, подающихся в реакционный канал, то при сжигании они будут занимать верхнюю часть выгазованного пространства, создавая там наиболее высокую температуру. Таким образом, почва водоупора над угольным пластом подвергается наибольшему термическому воздействию. Этот пласт прогревается над реакционным каналом в период сжигания угля и остывает после прекращения дутья. Водоносный пласт сверху нагревается под воздействием теплового потока, проходящего через кровлю нижележащего водоупора.

\section{Математическая модель.}

В оценке геотехнологии важно определить долю тепловой энергии, поступающей через водоупор в водоносный пласт, которую возможно отобрать путём откачки нагретой воды. При этом интенсивность подогрева подземных вод и мощность теплового потока напрямую зависят от объема саженного угля, и следовательно, от дутья, поданного в реакционный канал. Необходимое количество воздуха $\left(\mathrm{M}^{3}\right)$ для газификации 1 кг угля определяется по эмпирическому соотношению [5]:

$V_{\mathrm{B}}=\alpha \frac{0,001 Q_{\mathrm{y}}+25,1 W_{\mathrm{y}}}{418}$.

Производительность подземного газогенератора характеризуется объемом отработанного угля за определенный промежуток времени, и может быть записана в следующем виде

$\Pi=\frac{D}{V_{\mathrm{B}} \cdot \rho_{\mathrm{y}}}$.

Выход газа с 1 кг угля составит

$V_{\text {г }}=\frac{1}{V_{\mathrm{y}}}, V_{\mathrm{y}}=\frac{12 \sum C_{\text {уг.комп. }}}{22,4 \cdot C_{\text {уг }}}$,

$\sum C_{\text {уг.комп. }}=\% \mathrm{CO}_{2}+\% \mathrm{CO}+\% \mathrm{CH}_{4}$.

Принудительное нагнетание в газогенератор дутья дополнительно создаст вертикальный градиент давления, являющийся основной причиной конвекции в покрывающих породах [6]. При этом суммарный тепловой поток идущий от канала газификации на нагрев водоупора будет равен

$q_{0}(t)=q_{c d}(t)+q_{c v}(t)$.

Считаем, что теплофизические свойства пород водоупора не зависят от водообмена в вышележащем пласте.

Площади конвективного и кондуктивного теплообмена изменяются с течением времени по мере развития реакционного канала и сжигания угля. Согласно данным вскрытия подземных газогенераторов на Шахтинской и Лисичанской станциях "Подземгаза", теплофизические и геометрические параметры канала не постоянны, а связь между пустотами в нем носит местный и ограниченный характер [7]. Это связано с тем, что первоначально созданный канал в процессе газификации постоянно расширяется, приближаясь к кровле и подошве угольного 
пласта. В результате этого в выгазованное пространство попадают не только угольные, но и породные стенки. Далее сечение канала продолжает увеличиваться и, достигнув предельных величин, уменьшается вследствие обрушения породной кровли. Затем картина изменения сечения канала повторяется вновь.

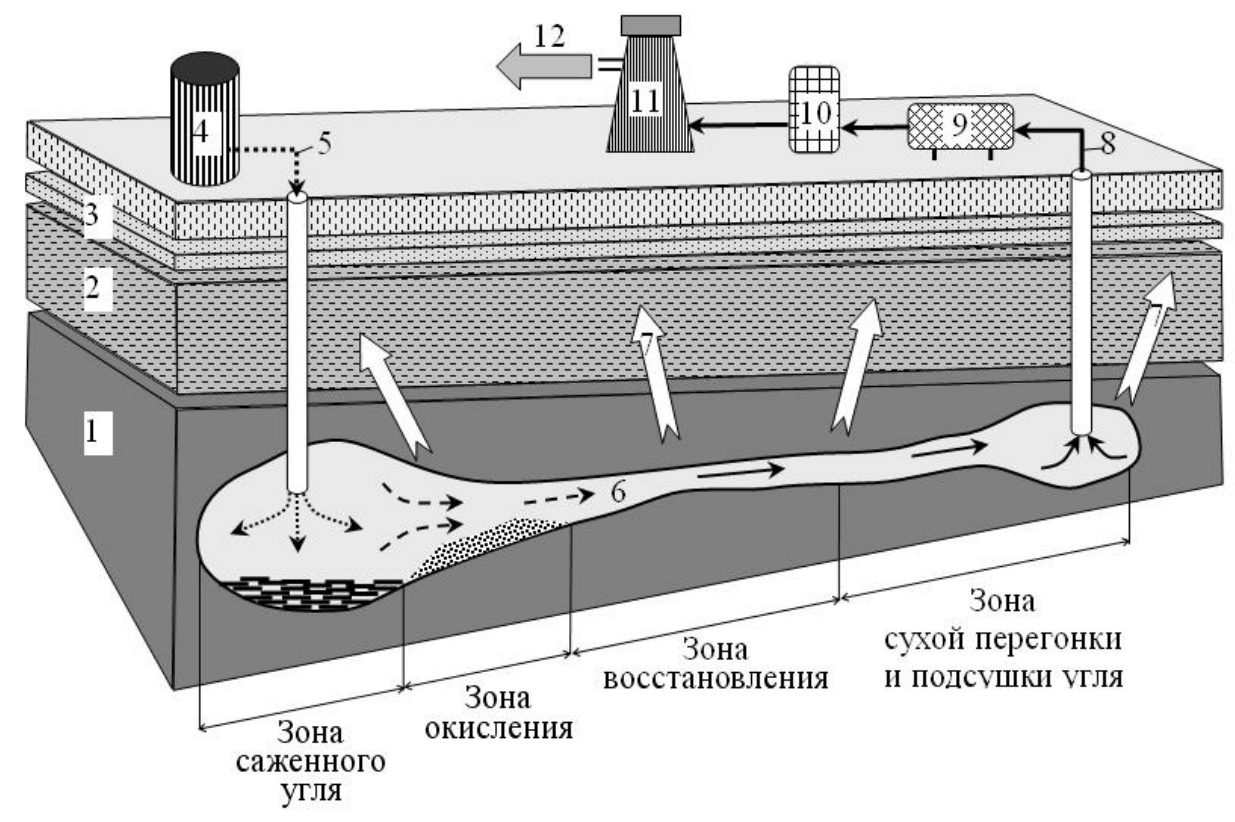

Рис. 2. Горно-энергетический модуль подземного сюигания угля:

1 - угольный пласт; 2 - водоупорные породы; 3 - водоносный горизонт; 4 - компрессор; 5 -дутье; 6-подземный газотеплогенератор; 7-тепловой поток в покрывающие породы; 8 - продуктивный газ, 9, 10 - соответственно оборудование для механической и химической очистки газа; 11 - теплообменник; 12 - тепловая энергия.

Учитывая, что в горно-геологических условиях угольных месторождений Украины сжиганию подвергаются пласты мощностью менее 1 м, реакционный канал относительно быстро достигнет их кровли и подошвы. Дальнейшее развитие выгазованного пространства будет происходить по всей мощности пласта в ширину. Его площадь может быть осреднена по времени с учетом удельной эффективности работы канала газификации [8]. $\ni=\frac{F_{\text {уп }}}{l_{\text {уп }}}$.

Конвективный тепловой поток, поступающий через водоупор в водоносный горизонт, определяется по формуле

$$
q_{c v}=\vartheta_{\Gamma} c_{\Gamma} \rho_{\Gamma}\left(T_{\Gamma}-T_{\text {пв }}\right), \vartheta_{\Gamma}=\frac{\kappa_{\Pi}}{\mu_{\Gamma}} \cdot \frac{P_{\Gamma}^{2}-P_{\text {атм }}^{2}}{2 P_{\text {атм }} \cdot H} \cdot S_{c v} \cdot
$$

Принимается, что давление газа одинаково в объеме полости. При высокой скорости филь- трации газа, достигающей нескольких мм/с, конвективный тепловой поток в течение суток поступает в водоносный горизонт. При этом нагревается небольшой объем вокруг трещин, а основная масса пород водоупора прогревается вследствие кондуктивного переноса тепла.

Пусть $\chi=q_{c v} / q_{o}$ - доля конвективного потока в общем потоке тепла через водоупор. Оставшаяся часть тепла $(1-\chi) q_{o}$ поступает в вышележащие породы кондуктивным путем. Оценки показывают, что $\chi$ не превышает несколько процентов даже при значительном увеличении проницаемости водоупора.

Кондуктивный поток тепла поступает в водоупор на разных участках по мере продвижения огневого забоя. В соответствии с принятой дискретизацией времени на всех участках подошвы водоупора над газогенератором в численных расчетах задается тепловой поток, 
соответствующий среднесуточному значению $q_{c d}$, причем для всех моментов времени $q_{c d}=(1-\chi) q_{0}$.

Кондуктивный тепловой поток пространственно распределяется по подошве водоупора. Для каждого $j$-го участка, где происходило поступление тепла с момента $t_{i}, q_{c d}$ можно задать ограничения:

$q_{c d j}= \begin{cases}q_{j}, & t_{i}<t<t_{i+1}, \\ 0 & t<t_{i}, t>t_{i+1} .\end{cases}$

Температура в слое водоупора над каждым участком суточного поступления тепла рассчитывается по формуле

$$
\begin{aligned}
& T_{j}(z, t)=T_{o}+q_{j}\left(T(z, t)-T\left(z, t-t_{s}\right)\right), \\
& T(z, t)=\frac{2}{\lambda_{\Pi}} \sqrt{a_{\Pi} t} \operatorname{ierfc} \frac{z}{2 \sqrt{a_{\Pi} t}} .
\end{aligned}
$$

Формула (8) представляет собой аналитическое решение уравнения теплопроводности в однородной полуограниченной области, на границе которой задан постоянный единичный тепловой поток [7].

Тепловой поток на кровле водоупора можно определить по формуле

$$
q_{c d, w}(t)=\left.S_{c d} \lambda_{\Pi} \cdot \frac{\partial T(t)}{\partial z}\right|_{z=m_{0}} .
$$

Суммирование выражений (9) по всем участкам пространственной дискретизации определяет общий кондуктивный поток, поступающий в пласт.

Расчет теплового потока с использованием решения (8) несколько занижает реальное поступление тепла в проницаемый пласт. Фактически отбор тепла фильтрационным потоком снизит температуру на подошве пласта и увеличит отток тепла из водоупора. Однако этот эффект будет незначительным ввиду небольшой разницы, температур нагретой воды и ее фоновой (естественной) температуры в пласте.

Отбор тепла, поступающего в водоносный горизонт, возможен через откачивающую скважину, расположенную в водоносном пласте вблизи канала газификации. Предположим, что весь поток условно мгновенно затрачивается на нагрев воды поступающей в скважину, и она сразу же удаляется из пласта. Тогда температура воды в скважине может быть рассчитана по формуле

$$
T_{s k}(t)=T_{\text {пв }}+\frac{q_{c d}(t)+q_{c v}(t)}{c_{\text {пв }} \rho_{\text {пв }} \mathrm{O}_{s k}(t)} .
$$

Более точная оценка величины $T_{s k}$ может быть дана на основе численного моделирования теплопереноса в проницаемом пласте с учетом вертикального расположения скважины и динамики поступления тепла.

\section{Метод решения и исходные данные.}

Сопоставительные расчеты по формулам (1) - (10) были выполнены в программной среде Mathcad для горно-геологических условий участка «Ольхово нижнее», расположенного в пределах Чистяково-Снежнянского угленосного района Донецкого бассейна. Каменоугольные отложения данной территории представлены смоляниновской свитой $\left(C_{2}^{3}\right)$, в разрезе которой между отрабатываемыми угольными пластами $h_{8}$ и $h_{11}$ развиты несколько нерабочих угольных пластов $\left(h_{9}, h_{10}{ }^{t}, h_{10}{ }^{1}\right)$ с углами падения от 10 до $30^{\circ}$ [9]. Данные пласты имеют простое строение, повсеместное распространение в пределах выделенного участка и относятся к антрацитам. Для свиты $C_{2}{ }^{3}$ характерно развитие обводненной толщи «бабаковских» песчаников $h_{10} S h_{11}$ мощностью $50 \ldots 60$ м, залегающих выше угольного пласта $h_{10}{ }^{1}$. В пределах этой толщи подземные воды имеют гидрокарбонатно-кальциевый состав с минерализацией до 3 г/л и не используются для питьевого водоснабжения. Учитывая требования, предъявляемые к угольным пластам, отрабатываемым способом ПСУ $[2,5]$ и фактические данные о строение участка, можно считать, что на данной территории оптимальным будет разработка угольного пласта $h_{10}{ }^{1}$ с использованием в качестве теплоносителя воды песчаников $h_{10} S h_{11}$.

Теплофизические свойства и геотехнологические параметры ПСУ принимались следующими: $\alpha=1,1 ; Q_{\mathrm{y}}=15$ МДж/кг; $W_{\mathrm{y}}=35 \%$; $\rho_{г}=1,1 \kappa \Gamma / \mathrm{M}^{3} ; \rho_{\text {у }}=1000 \kappa \Gamma / \mathrm{M}^{3} ; \sum C_{\text {уг.комп }}=39 \%$; $C_{\text {уг }}=65 \% ; c_{\text {г }}=1000$ Дж/кг ${ }^{\circ}{ }^{\circ} ; \mu_{\Gamma} \stackrel{\text { уг.комп }}{=} 1,79 \cdot 10^{-5}$ кг/ $\mathrm{M}^{\mathrm{yг}} \mathrm{c} ; T_{\mathrm{r}}=900{ }^{\circ} \mathrm{C} ; \kappa_{\mathrm{r}}=10 \ldots 14 \mathrm{M}^{2} ; P^{\mathrm{r}}=0,102 \mathrm{MПа}$ $\lambda_{\text {п }}=2,5 \mathrm{BT} / \mathrm{M}^{\circ}{ }^{\circ} \mathrm{C} ; T_{\text {пв }}^{\text {Г⿸ }}=15{ }^{\circ} \mathrm{C} ; c_{\text {пв }}=4100$ Дж $/ \mathrm{\kappa} \Gamma{ }^{\circ} \mathrm{C}$; $\rho_{\text {пв }}=1000 \mathrm{\kappa} / \mathrm{M}^{3} ; \mathrm{H}=200 \mathrm{M} ; P_{\text {г }}^{\text {пв }}=3 \mathrm{MПа} ; t=20$ сут; $D=1800 \mathrm{~m}^{3} /$ час. Площадь теплообмена задавалась как объем выгазованного пространства 
при мощности угольного пласта один метр. Тепловой поток, поступающий в породы кровли подземного газогенератора, определялся как разность между теплотой сгорания угля и теплом заключенным в вырабатываемом при этом газе

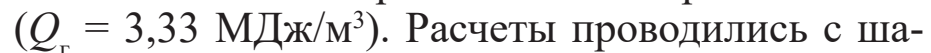
гом по времени в одни сутки.

\section{Результаты моделирования.}

На рис. 3 - 4 приведены результаты расчета суммарного теплового потока поступающего в вышезалегающий водоносный горизонт и температуры насыщающих его подземных вод в процессе сжигания угольного пласта. Кривые (а) и (б) получены при различных мощностях водоупора. Анализ показывает, что с увеличением размеров разделяющего слоя количество тепла проникающего в водоносный пласт уменьшается, что очевидно, но доля конвективной составляющей в общем потоке тепла возрастает с 6,5 до 9,3 \% при увеличении мощности водоупора с 3 до 7 м соответственно. Температура откачиваемых подземных вод в период сжигания угля доходит до $90{ }^{\circ} \mathrm{C}$ и уменьшается с увеличением дебита скважины и мощности водоупорных пород. После прекращения процесса сжигания угля она резко снижается и достигает своих начальных значений спустя 100 сут.

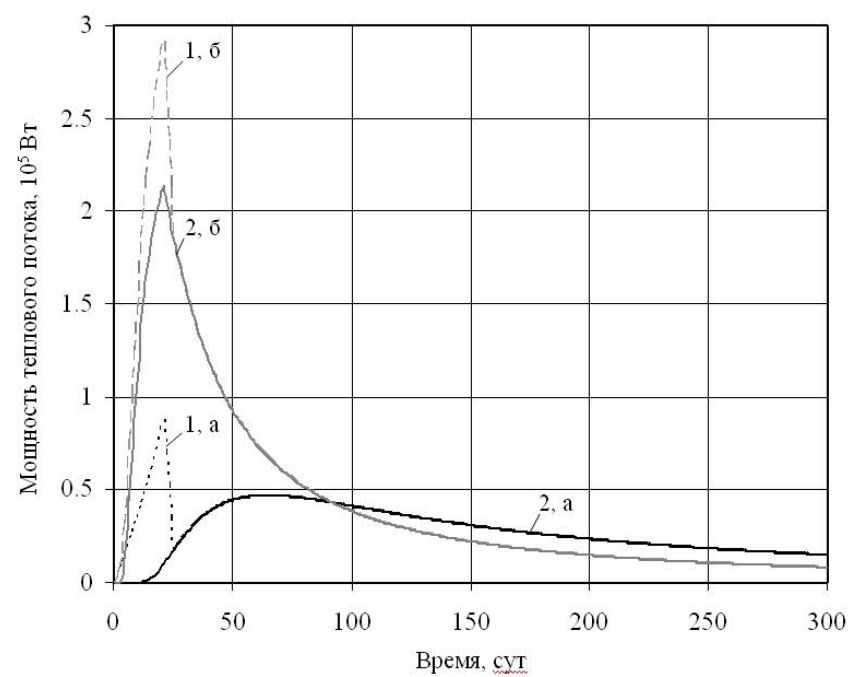

Рис. 3. Изменение конвективной (1) и кондуктивной (2) составляющей теплового потока, поступающего в водоносный горизонт при подземном сжсгании угольного пласта с водоупорными породами мощностью 7 (a) и 3 м (б).

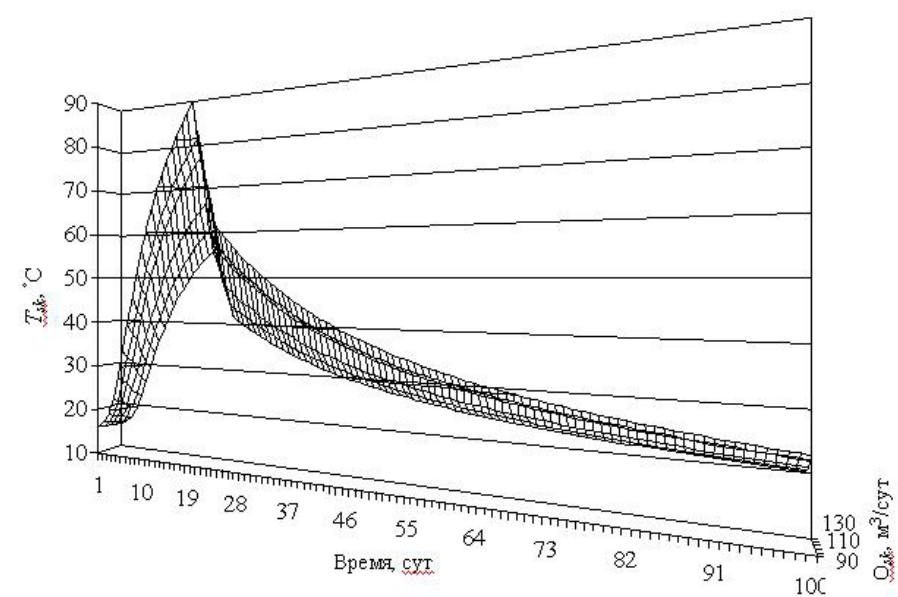

Рис. 4. Изменение температуры подземных вод, отбираемых скважиной из водоносного пласта, залегающего над подземным газогенератором. 
На рис. 5 представлен тепловой баланс ПСУ. Анализ диаграмм показывает, что большая часть (64 \%) тепла сжигаемого топлива содержится в вырабатываемом газе. На долю физического тепла (попадающего в горный массив) приходятся оставшиеся $36 \%$. В водоносный горизонт, в зависимости от мощности водоупора (3...7 м), поступает от 18 до 25 \% выделяющейся в про- цессе сжигания тепловой энергии. Остальное физическое тепло поглощается вмещающими породами. Отбор нагретых вод из водоносного пласта позволяет использовать аккумулирующуюся в водоносных породах тепловую энергию и тем самым повысить КПД процесса подземного сжигания до $85 \%$.

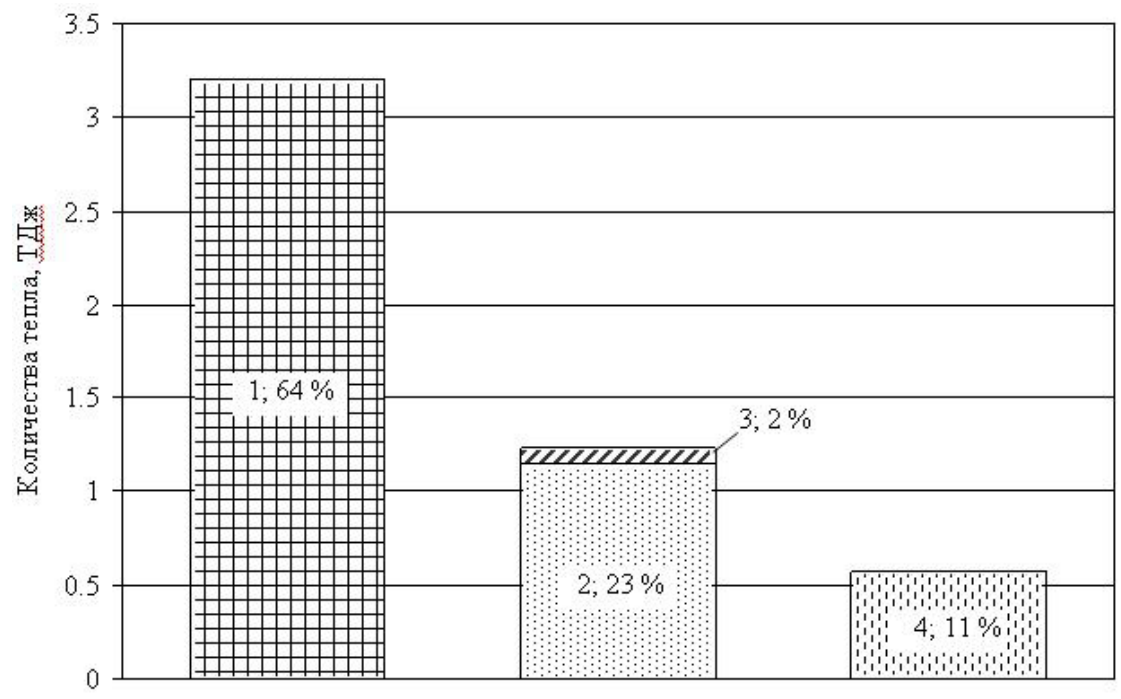

Рис. 5. Баланс тепловой энергии при подземном сжигании некондиционного угольного пласта участка «Ольхово нижнее»:

1 -химическое тепло, заключенное в газе ПСУ; 2 - 3 -тепло, поступающее в водоносный горизонт кондуктивным и конвективным путем соот-ветственно; 4 - физическое тепло, поглощценное породным массивом.

Цифрами показана доля тепла от общей теплоты сгорания топлива в процентах.

\section{Выводы.}

Разработана модель теплопереноса в породах кровли подземного газогенератора при сжигании угольного пласта. Использованные при тестировании модели горно-геологические и теплофизические параметры соответствуют условиям реального угольного участка, пригодного для отработки способом подземного сжигания. Выполненные расчеты позволили оценить роль конвективной и кондуктивной составляющей теплового потока в нагреве подземных вод вышезалегающего водоносного горизонта. По результатам моделирования установлены количественные показатели уменьшения величины потока и температуры подземных вод с увеличением мощности водоупорно- го слоя и дебита эксплуатационной скважины. Тепловой баланс ПСУ показал, что в водоносном пласте накапливается от 18 до 25 \% тепла, выделяющегося при сжигании угля. Это позволяет существенно нагреть (до $90{ }^{\circ} \mathrm{C}$ ) насыщающие его подземные воды, использовать их для теплоснабжения зданий и повысить КПД подземного сжигания до $85 \%$.

Дальнейшее развитие данной модели целесообразно путем повышения ее адекватности реальной геотехнологической схеме, которая предполагает одновременную закачку и отбор воды разной температуры через систему нескольких скважин. Кроме того, необходима оценка экономической эффективности использования тепловой энергии водоносных горизонтов при ПСУ на основе результатов моделирования. 


\section{ЛИТЕРАТУРА}

1. Тополов B.C. Угольная отрасль Украины: энергоресурсы, ретроспектива, состояние, проблемы и стратегия развития / В.С.Тополов, Б.А.Грядущий, С.Я.Петренко. - Д.: ООО «Алан», 2005. -408 c.

2. Крейнин Е.В. Нетрадиционные термические методы добычи трудноизвлекаемых топлив: уголь, углеводородное сырье / Е.В. Крейнин. М.: ООО «ИРЦ Газпром», 2004. - 302 с.

3. Садовенко И.А. Миграция и теплоперенос вокруг подземного газогенератора: Монографія / И.А. Садовенко, А.В. Инкин, С.В. Жолудев. Дніпропетровськ: «Грани», 2012. - 282 с.

4. Lindblom S.R. Rocky Mountain 1 Underground Coal Gasification Test Hanna, Wyoming Groundwater Evaluation. Final Report June 10, 1988 - June 30, 1993 / S.R. Lindblom, V.E. Smith. - 1993. $-84 \mathrm{p}$.

5. Теория и практика термохимической технологии добычи и переработки угля: Моног- рафия / [под. ред. О.В. Колоколова]. - Днепропетровск: НГА Украины, 2000. - 281 с.

6. Аренс В.Ж. Контроль и управление процессом подземной газификации угля / В.Ж. Аренс, И.М. Бирман // Геотехнология топливно-энергетических ресурсов: Сб. науч. тр. - К.: Наук. Думка, 1986. - С. 220 - 230.

7. Ариненков Д.М. Подземная газификация угля / Д.М. Ариненков, Л.М. Маркман. - Сталино: Сталино-Донбасс, 1960. - 96 с.

8. Гончаров C.A. Термодинамика: Учебник / Гончаров С.А. - М: Издательство Московского государственного горного университета, 2002. $440 \mathrm{c}$.

9. Геология месторождений угля и горючих сланцев СССР. Т. 1. Угольные бассейны и месторождения юга Европейской части СССР / [Лагутина В.В., Левенштейн М.Л., Попов В.С. и др.]; под ред. И.А. Кузнецова. - М.: Госгеолтехиздат, 1963. $-1210 \mathrm{c}$. 


\section{PROSPECTS OF USE OF THERMAL ENERGY IN AQUIFERS UNDERGROUND BURNING OF COAL}

\section{Sadovenko I.A., Inkin A.V.}

State HEI «National Mining University» of the Ministry of education and science of Ukraine, Karl Marx Av., 19, Dnipropetrovs'k, 49600, Ukraine

Key words: underground coal combustion, thermal energy, underground water.

Purpose. Installing the dynamics of formation of a thermal field around underground gas generator and the possibility of withdrawal of ground water are heated to heat buildings.

Methods. Developed and applied methods based on numerical modeling of convective and conductive heat flow component that penetrates from the reaction channel in the aquifer which lies above. Verification of the model made for the geological conditions of the site «Olho bottom», located within Chistyakovo-Snizhne carboniferous region Donetsk basin.

Results. The estimates varying the heat flux and temperature in groundwater depending on capacity impermeable layer deterioration. Based on numerical analysis found that by the end of working coal aquifers in the array can accumulate more than $60 \%$ of the heat that enters the host rocks. The selection of the heated water will enhance the efficiency of POC to $85 \%$.

Reefrences 9, figuers 5.

1. Topolov V.S. The Ukrainian coal sector: energy, retrospection, status, problems and development strategy N.S.Topolov, B.A.Gryaduschiy, S.Ya.Petrenko.Donetsk: OOO «Alan», 2005. - 408 p. (Rus.)
2. Kreinin E.V. Unconventional thermal methods of extraction of unconventional fuels: coal, hydrocarbons / E.V. Kreinin. - Moscow: OOO «IDC Gazprom», 2004. - 302 p. (Rus.)

3. Sadovenko I.A. Migration and heat transfer around underground gas generator: Monograph / I.A. Sadovenko, A.V. Inkin, S.V. Zholudev. Dnipropetrovs'k: «Grani», 2012. - 282 p. (Rus.)

4. Lindblom S.R. Rocky Mountain 1 Underground Coal Gasification Test Hanna, Wyoming Groundwater Evaluation. Final Report June 10, 1988 - June 30, 1993 / S.R. Lindblom, V.E. Smith. - 1993. - 84 p. (En.)

5. Theory and practice of thermo-chemical technology of booty and processing of coal: Monograph/[ed.O.V.Kolokolov].-Dnipropetrovs'k: Natsionalnaya gornaya akademiya Ukrainyi, 2000. 281 p. (Rus.)

6. Ahrens V.Zh. The control and management of the process of underground coal gasification / V.Zh. Arens, I.M. Birman // Geotehnologiya toplivno-energeticheskih resursov: $\mathrm{Sb}$. nauch. tr. Kiev: Nauk. Dumka, 1986. - P. 220 - 230. (Rus.)

7. Arinenkov D.M. Underground coal gasification / D.M. Arinenkov, L.M. Markman. - Stalino: Stalino-Donbass, 1960. - 96 p. (Rus.)

8. Goncharov S.A. Thermodynamics: Tutorial / Goncharov S.A. - Moscow: Izdatelstvo Moskovskogo gosudarstvennogo gornogo universiteta, 2002. -440 p. (Rus.)

9. Geology of deposits of coal and pyroshales of the USSR. Vol. 1. Coal pools and deposits of south of European part of the USSR / [Lagutina V.V., Levenshteyn M.L. and Popov V.S.]; ed. I.A. Kuznetsov. - Moscow: Gosgeoltehizdat, 1963. 1210 p. (Rus.)

Получено 11.01.2016 Received 11.01.2016 